Nachdruck verboten.

Übersetzungsrecht vorbehalten.

\title{
The Morphology of Coeloplana.
}

\author{
By
}

Prof. James Francis Abbott.

(Washington University, Saint Louis, Missouri, U. S. A.)

With plates $8-10$ and 7 figures in the text.

Contents.

A. Historical . . . . . . . . . . . . . . . . . 42

1. Kowalevsky's Coeloplana . . . . . . . . . . . 42

2. KorotnefF's Ctenoplana. . . . . . . . . . . . 43

3. WILLEY's Cienoplana . . . . . . . . . . . . . 44

B. The Japanese Coeloplana . . . . . . . . . . . . . 45

1. The living animal; life habits . . . . . . . . . . 46 External appearance . . . . . . . . . . . . 47

2. Structure of Coeloplana . . . . . . . . . . . . 49

a) Epithelium . . . . . . . . . . . . . . . . . . . . . 49

b) Gastro-vascular system . . . . . . . . . . . 51

General organization . . . . . . . . . . 51

Histological structure . . . . . . . . . . . 53

c) Tentacles and related structures . . . . . . . . 55

General description . . . . . . . . . . . 55

Histological structure . . . . . . . . . . . 56

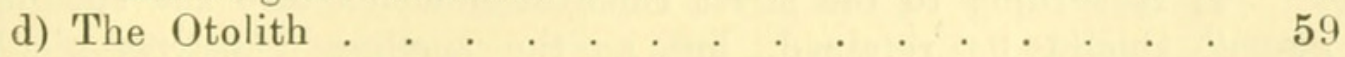

e) Parenchyma and musculature . . . . . . . . . . . . 61

C. General considerations . . . . . . . . . . . . 61

D. Summary . . . . . . . . . . . . . 65 
The following account deals with the details of structure and homologies of "Coeloplana", a form hitherto known only from a superficial description of a single specimen. The material for the present paper was described in a preliminary note in: Annotationes Zoologicae Japonenses, Vol. 4, 1902, but press of other duties has made it impossible to complete the work until now.

\section{A. Historical.}

\section{Kowalevsky's Coeloplanc.}

- In 1881, Kowalevsky discovered in the Red Sea near the city of Tor, a form to which he gave the generic name Coeloplana ${ }^{1}$ ), in allusion to the apparent combination of Coelenterate and Planarian characters which it afforded. KowaLevsky's report was published in the proceedings of the Zoological Section of the Sixth "Convention of Russian Naturalists and Physicians". ${ }^{2}$ ) It was reviewed in the "Zoologischer Anzeiger", and our knowledge hitherto has depended upon this latter rather brief account. The Russian naturalist described his single specimen as grayish above and white ventrally, round in outline and measuring about three lines in one direction by two lines in the other. It was found on Zostera at a depth of 10 to 15 fathoms and was mistaken for a planarian until his attention was attracted by the extrusion of the tentacles. The abstract in the Zoologischer Anzeiger describes Coeloplana as ciliated all over and KowaLevskr's figure shows cilia all about the periphery but he makes no such statement in the original paper. The animal was described as "Planarian-like". There was a median ventral mouth leading directly into a central gastric cavity from which branching canals ramified. Four main divisions led off from the central cavity and divided up into many subdivisions, separated by trabeculae connecting the upper and lower body walls. These canals according to Kowalevsky opened into a circum-peripheral canal from which extended blind processes. Above the mouth was a Ctenophor-like

1) According to the strict rules of nomenclature the spelling "Coeleplana" should be retained, but as the spelling "Coeloplana" has been used constantly since KowALEVSKY's paper and for orthographic reasons is so very much to be preferred, it has seemed best to continue its use in the present paper.

2) Извъст. общ. люб. естествоз. Vol. 43. Труды. зоол. отдъла. Vol. 1. 
otolith sac with its enclosed otolith. On either side surrounding it, were two curious half moon shaped diverticula of the gastric cavity. ${ }^{1}$ )

In the opposite plane were the characteristic Cydippid tentacles each enclosed in a flask-shaped sheath.

Notwithstanding its Planarian-like appearance Kowalevsky concluded that so far as his rather superficial examination went, Coeloplana was more Ctenophore than Flatworm. He considered the plane of the tentacles as right and left, that is, sagittal.

\section{KorotnefF's Ctenoplana.}

Some four years later, another Russian scientist, ALExis Korotnefr, caught in the tow-net, on the west coast of Sumatra, a single specimen of an animal that was very evidently closely related to Coeloplana but presenting marked points of difference. This form was much more like a typical Ctenophore than Coeloplana and to it Konotneff gave the name Ctenoplana. In addition to the characteristic otolith and tentacles which had been described for Coeloplana, Korotneff also described eight rows of Ctenophoral costae, the individual combs of which, however, were reduced to seven in number. Each costal row was retractile into a cup-shaped cavity of the body wall. The rows of costae were separated in one plane by the tentacle sheathes and between the other rows the body was thrown up into folds, - the whole effect being to give a stellate appearance tothe dorsal surface. In KonotnefF's figure there is a notch in the periphery on either side, in the plane at right angles to the tentacular plane.

About the otolith was a circlet of sensory tentacles (11 in his figure) and the whole body surface is described at ciliated. KовотNefF described and figured the structure of the otolith and its cup in some detail. According to him the mouth leads directly into a central cavity from which the gastric canals arise, and above which there is a structure like the Ctenophor infundibulum, consisting of

1) The abstract in the Zoologischer Anzeiger reports these: "Vor und hinter diesem Bläschen (i. e. the otolith) gewahrt man die erweiterten scheinbar blinden Enden zweier Canäle, die vom Magen ausgehend gegen die dorsale Körperfläche gerichtet sind". The obvious but misleading interpretation of this statement seems to have lead LANG astray in one of his homologies. Vide post. 
a cup-shaped cavity just below the otolith sac. The presence of any circumperipheral canal is denied. He also described a remarkable structure in the neighborhood of the tentacles, - a cavity in which lie large and powerful longitudinal muscles and which opens to the exterior by a pore. He conceives this to be possibly excretory in function, and surmises that it may be homologous with the watervascular system of Planarians. However, as Willex suggests, there is no doubt that KonotnefF was describing a section through the tentacles, which he was unable to orient correctly. The muscular fibers of the tentacle stalk might well be mistaken for "longitudinal muscles".

\section{Willey's Ctenoplana.}

No further discoveries of either Ctenoplana or Coeloplana were reported until Arthur Willex, in 1896, in the course of his investigations in the South Seas, discovered 4 specimens of KonotnefF's Ctenoplana, apparently belonging to different species, three of the specimens being greenish and one crimson. WiLlex was able to keep them under observation in the living state some time and established the fact that Ctenoplana swims through the water as a Ctenophore does, solely by the aid of its costae. The most important contribution that he was able to add to the morphology of the form was the discovery of the male gonads, which are described as being located "at the bases of the two end-lobes of the main portion of the gastro-vascular system" and hence apparently radially disposed in relation to the otolith.

The most striking thing in Willer's description is that these gonads open to the exterior, dorsally, by one or more simple ducts the mouths of which lie just below the level of the surmming plates. The cell proliferations which constitute the testis are developed upon the outer walls of the coeca from the gastric canals. The whole arrangement is strikingly at variance with anything we are familiar with in either Coelenterates or Platyhelminthes. WILLEY asserts that the dorsal surface bears no cilia. He further states that the sensory tentacles near the apical sense organ, instead of forming a closed circle, as described by KовотNefF in reality are arranged in two semicircular areas on either side of the otolith sac, - the circle being broken in the line of the tentacular plane. WILLEY's figures are unsatisfactory inasmuch as he does not attempt 
to trace the course of the gastric canals. As far as one can make out, the costae, as figured, seem to lie between large, lobed diverticula of the central gastric cavity, in contrast to the condition usual in Ctenophors, in which the rows of costae overlie the meridional canals.

WiLley's discoveries led him to institute some interesting homologies and hypotheses which will be taken up further on.

\section{B. The Japanese Coeloplana.}

In the summer of 1901 it was the writer's good fortune to discover, at Misaki, Japan, some specimens of what were very evidently Kowalevsky's "Coeloplana". Devoting himself the next summer to a renewed search he was further rewarded by finding several more, and altogether, that year and the next, some thirty or more specimens were obtained, some of which, however, were lost in aquaria and through poor fixing agents. The Coeloplanae were all obtained from two localities facing the open bay each a few square rods in area. One of these was the rocky beach immediately fronting the Marine Station and the other below the place known locally as "Dojin no Haka". Both these areas are covered with broken rocks and boulders and are exposed to rather high surf in rough weather. At the times of lowest tides the Coeloplanae may be found at a depth of about two feet, clinging to the small coralline covered stones on the bottom, but they are very rare even in the most favorable localities, and the hunt for them is frequently discouraging. Apparently the animals are never to be found in a tidepool where the water might be left by the receding tide and grow stale or warm in the sun's rays. Two species occured together, one a bright pink or red in color and the other smaller and chocolate brown. The two were found together in the same locality but always so situated as to make detection extremely difficult, owing to the resemblance between the animal and the stone or alga upon which it was fastened. I have never seen them floating or caught them in the tow-net but they have always been extended on the surface of the stone and fastened by slime so that they tenaciously resisted being taken off, and it was usually found more satisfactory to bring the stones into the laboratory when possible, and carefully force them off with a pipette. The Coeloplanae are found frequently on large rocks, stretched out into a thin shapeless film of slime hardly suggestive of anything animal. Such a specimen 
so extended may measure 5 or $6 \mathrm{~cm}$ across in longest diameter, shrinking to one-fifth that diameter when contracted.

\section{Life habits.}

Coeloplana cannot swim, either as a ctenophore, or by means of the flattened skirt of the body, as some planarians do. I have never found it floating, but in the quiet of the aquarium it usually came to the top and spread itself out, adhering to the surface of the water by the ventral face of the body, as a planarian. In this habit of floating it seems to resemble Willuey's Ctenoplana. At such times Coeloplana, especially C. mitsukurii, throws out its long delicate tentacles which hang down in the water and wave about in very graceful fashion, and then the great length of the tentacles in comparison with the size of the body is made apparent (Fig. 2). If disturbed when so floating, - either by the water being agitated or by the body being touched by a foreign substance, - it falls to the bottom in a shapeless lump. Willey describes his Ctenoplana as folding together like a book under such circumstances, but there is no such axis of flexure in Coeloplana. If dropped, dorsal side uppermost, it rights itself without difficulty. Many experiments and observations were made to ascertain whether the animal crawled in any one direction rather than in another, and it was proved conclusively that it did not. The act of crawling seems to be wholly a response to peripheral stimuli and as such stimuli may act on two or more sides at once, we have the remarkable spectacle of two sides of the animal progressing in different directions. As noted by Kowalevsky this mode of progression is, in a sense, amoeboid. A projection of the body is pushed out and the rest of the body tissue behind it, follows on. When the animal is crawling, the whole periphery of the body is thrown into folds and outpushings. This is especially to be noted in the red form, $C$. willeyi, where no consistent body shape is maintained and where different sections of the body may overlap each other. One result of such a habit is that the internal structures become twisted about so as to defy orientation. When the animal is very active it will often, while crawling, throw out the tentacles in a cloud of white filaments. The whole mass of filaments seems to be expelled at once and then to be slowly withdrawn. The ejection of the tentacles is effected by a sudden contraction of the muscular walls of the sheath. The two tentacles 
may be ejected alternately or together. Touching the periphery with a needle will often cause one or both of them to be protruded a short distance, but I was never able by such means to get the whole tentacle thrown out.

External Appearance.

Measurements of the size of Coeloplana are not of much value in an animal of such great mobility. When fully contracted the shape of the body in both species is nearly circular. C. willeyi, in such a condition usually measures $1-2 \mathrm{~cm}$ across, and $C$. mitsukurii, $1 \mathrm{~cm}$ or less, - usually about $5 \mathrm{~mm}$. Dorsally, the two species differ markedly in color. C. willeyi varies from pale rose to deep scarlet, the intensity of the color in an individual depending of course in large measure upon whether the animal is contracted or extended. Similarly the smaller species, C. mitsulurii, ranges from an almost pigmentless condition to a deep chocolate brown. The former species was nearly always found on red Zostera, while the latter favored Melobesia or the bare brown stone. About the periphery there is a series of white or whitish-yellow spots or flecks of color (Fig. 1). These seem also to be indicated in KonotnefF's drawing. I have been unable to identify them in fixed material or in sections. It may be possible that they are sensory in function and sensitive to light but I have no evidence on the point. It is worthy of note that these spots almost invariably occur opposite a slight notch or puckering of the periphery. In both species there is, as in Ctenoplana, a rather prominent notch opposite the openings of the tentacle sheathes.

The sheath containing the tentacle filaments lies as a loglike ridge on either side of the otolith and is made especially prominent by being more heavily pigmented than the rest of the body. The sheath terminates exteriorly in a sort of tubelike papilla, a trifle back of the peripheral notch mentioned above. The papilla lies free above the surface, and when the animal is extended may be retracted so as to leave only the opening on the dorsal surface.

The otolith is comparatively small and in $C$. willeyi almost insignificant in size. It lies in a pit closed by fleshy lips and, in the living animal, is frequently difficult to find.

Next to the tentacles the most prominent thing to be observed in the living animal is the network of anastomosing gastric canals. These are much less prominent in C. mitsukurii on account 
of its opacity, but in $C$. willeyi they are very evident and the circulation may easily be watched with a low power. It may then be seen that the colorless elements of the circulating fluid are driven through the canals with considerable rapidity. The speed of the circulating current varies with the movements of the animal and, in the peripheral portions at least, is apparently controlled solely by them. The disposition of the canals in the center of the body is very difficult to make out in the living animal but toward the periphery they branch much more profusely and it is seen that they form an anastomosing network, ending blindly in finger-like pockets and not fusing to form a circum-peripheral canal.

In connection with the canal system, dorsal respiratory tentacles are frequently to be observed, especially when the animal is floating ventral face upward, on the surface of the water (Fig. 2). These organs are superficially much like the cirri of Thysanozoon, and consist simply of hollow finger-shaped projections from the dorsal surface of the body, in direct communication with certain of the digestive canals. In $C$. willeyi these tentacles are cylindrical or slightly club-shaped (Fig. 1), whereas in C. mitsukurii they end in digitate processes which give them a fringed appearance and probably assist the animal in imitating the vegetable growth or the debris, in the midst of which it lives. The body tissue of $C$. willeyi is so loose and the animal itself so 'amoeboid' in its movements, that it is impossible to tell, in the living specimen, just what arrangement these dorsal tentacles have, and it is only by the aid of a series of sections that their relations may be worked out. But in C. mitsukurii the body is firmer in texture and its shape more consistent, so that the general arrangement may readily be observed. It is then seen that the tentacles are arranged about the sense organ as a center and radiate from it in four directions. There are 6 to 8 tentacles in each row, and the distal ends of the rows curve in toward the tentacular planes so that the four rows together assume somewhat the appearance of a figure 8 with the upper and lower curves broken. It is easily determined that these four rows follow four main channels of the digestive canal system. With a low power it may readily be seen that the fluid contents of these tentacles is in direct communication with that of the gastric canal immediately underneath, and the solid formed elements of the circulating fluid are caught and whirled about in eddies within the tentacles or at their bases. The very evident function of these 
organs would appear to be respiratory and this view is supported by the fact that the tentacles are seldom if ever protruded except when the water is a trifle stale. They do not seem to have any sensory function, as they may be touched or pushed aside with a needle without being withdrawn or causing any reaction in any other part of the animal. The tentacles themselves, in C. willeyi, are colorless but the epithelium at the base is heavily pigmented. In $C$. mitsukurii, on the other hand the fringed tentacles are densely pigmented and are hardly to be distinguished from incrusting debris.

\section{Structure of Coeloplana.}

a) Epithelium.

Compared with the ordinary Ctenophores, the epithelium of Coeloplana is relatively firm and well developed. There are at least four well marked cell elements in its makeup. 1) Gland cells, 2) Interstitial cells or interstitial syncytium, 3) Supporting (ciliated) cells, 4) Pigment cells.

Gland cells occur in great numbers all over the body, but are especially numerous at the periphery. They are fewest in number and smallest in the region directly over the tentacle sheathes, where the epithelium is also relatively much thinner. The various stages in the development of the gland cells, as worked out by Samassa are well represented in Coeloplana. The clear fluid contents of the cells becomes divided off into globules by thin sheets or trabeculae of differentiated cytoplasm, which increase in number and in size until the cell is gradually filled with an anastomosing network of fibrils that stain intensely in haemotoxylin and other basic dyes (Samassa's Stage B). The fluid contents of the intertrabecular spaces does not stain with either acid or basic dyes, at least not by any method tried so far. But at a certain point a sudden chemical and physical change intervenes and the staining reactions are reversed. The formerly fluid globules appear to gel or coagulate and stain intensely with eosine or other acid dyes, while the formerly very evident network either disappears or refuses to take any stain. This is the "Stage C" of Samassa. In any one preparation the majority of the gland cells will usually be found in either Stage B or Stage C, but in a very few instances I have found indications of the cell having been killed during the change Zool. Jabrb. XXIV. Abt. f. Aнаt. 
from one to the other. In these cells the lower part had changed over into the third or granular stage, while the distal end retained traces of the network (Fig. 33). The eosinophile granules of Stage C increase in size and swell the cell to its full capacity, - the result being that instead of these granules keeping their original rounded shape they become flattened by mutual pressure, like peas in a pod. The outer surface of the cell is bulged out until at dast the pressure becomes too great and the cellwall is ruptured, the granules passing to the exterior (Fig. 36). The nucleus of these cells is rather large, oval, or flattened, basal in position and full of chromatin granules. Occasionally cells are found (Fig. 36) of the same shape and general appearance as those of Stage B mentioned above, but filled with a very fine and delicate network of fibrils and with knots of deeply staining protoplasm at the nodes of the reticulum. The cytoplasm is granular, and the nuclei are relatively large and not flattened. It is possible that the secretion of these cells differs in character from that of the ordinary gland cell described above.

Between the gland cells of the epithelium, and especially surrounding them at the base is a syncytium of interstitial supporting substance, full of deeply staining nuclei. In places cellwalls may be made out and apparently there is no hard and fast line to be drawn between the condition of individual supporting cells and that of a true syncytium. Where the gland cells are very numerous and close together, as at the periphery, the nuclei of the supporting substance are very numerous and cellwalls are not discernable. When the gland cells are scattered and relatively less numerous and the intercellular tissue correspondingly greater in extent, cell outlines may frequently be traced downward from the external surface, fading away as they approach the basement membrane.

Ventrally the interstitial syncytium passes over into a definite cell structure, - the ciliated cells. These are narrow, columnar or sometimes flaskshaped, closely appressed, with an oval nucleus near the base and a granular cytoplasm. At the distal end are knots of deeply staining protoplasm, "microsomes", from which the heavy cilia arise. These cells are larger in the neighborhood of the mouth and in the pharynx. Here the microsome is large and prominent and the cilia arising from the surface fuse together (in fixed preparations at least) into a rather heavy flagellum. Whether this is the general condition of the cilia bearing cells over the 
whole ciliated surface I cannot say. In the living animal the cilia are very evident over the entire ventral surface.

Scattered over the basement membrane and through the adjacent parenchyma, and showing through the outer layer of epithelium, are numerous irregular, branching, pigment cells. These cells, so far as I have been able to make out, are confined to the dorsal surface. There is great variation in pigmentation, such cells being practically absent in some specimens. The substance of the cells is granular, and the color appears to be due to a deposit of some highly refractive material in tiny spherules. These are very likely similar to the iridocytes in the integument of fishes. The pigment cells are sometimes (but rarely) found among the epithelial cells proper. In nearly all cases they are found among the connective tissue and muscle cells that underlie the true epithelium. They are of course most numerous in C. mitsukurii and in both forms are most noticable at the bases of the dorsal tentacles and over the tentacle sheath. In $C$. mitsukurii they are very thickly scattered through the tissue of the fringed dorsal tentacles themselves, but are absent in the unbranched dorsal tentacles of $C$. willeyi.

The basement membrane is rather thick and is intimately connected with the connective tissue and muscle cells of the parenchyma.

b) Gastrovascularsystem.

General organization.

The mouth is large, roughly quadrangular or four lobed and lies immediately beneath the sense organ. It opens into a capacious pharynx or stomodaeum, the walls of which are thrown into a great number of folds. Plane section shows that the pharynx is not compressed in either plane but is approximately square in shape, the wall projecting into the cavity from four sides, in the tentacular and transverse planes. Kowalevsky describes the mouth of Coeloplana as leading directly into the stomach (infundibulum?) without the intermediate development of a pharynx, but the observation is a questionable one as he evidently did not preserve and section his specimen. The complicated pharynx in C. mitsukurii and C. willeyi is, in the living animal, extremely difficult to make out except under the most favorable circumstances, but it is very prominent in fixed and stained material. 
In the roof of this pharyngeal cavity is the opening of a vertical canal which leads up to the infundibulum and which with the pharynx itself comprises the stomodaeum. This canal is strongly compressed in the stomachal plane. Distally it opens into the cupshaped infundibulum, which lies just beneath the otolith capsule From the infundibulum four main canals arise, two in the sagittal (stomachal) and two in the transverse (tentacular) plane. The latter pair run to the muscular base of the pinnate tentacles, penetrate them and also spread out in a sort of anastomosing network enclosing the sheath. Lateral branches are sent out that ramify to the periphery, anastomosing and subdividing until they end in blind finger-shaped terminations. The other two main branches of the canal system arising in the sagittal plane, sometimes at a trifle lower level than those in the tentacular plane, subdivide into two canals. In some specimens this subdivision occurs so close to the infundibulum as to give the appearance of two independent canals, arising on either side. In most specimens however the parent stem is evident. The two secondary canals arising from its subdivision, run close to the dorsal surface of the body and are the ones which send out the processes described above as respiratory tentacles. As already indicated, the course of the canals is bent toward the tentacular plane so that the two pairs on either side assume roughly the form of a figure " 8 ". From these main canals smaller subdivisions arise all along the course which are continued downwards and laterally, anastomosing and uniting with those arising from the canals in the tentacular plane. In C. willeyi the peripheral digestive tracts partake more of the nature of sinuses, divided off from one another by trabeculae or partitions of connective tissue which extend from the dorsal body wall to the ventral. These trabeculae are especially evident near the periphery, but towards the center the lacunae take on the normal character of thin walled tubes. The "sinuses", then, are really greatly enlarged divisions of the canal system where the upper and lower walls have become confluent with the dorsal and ventral body walls and where the sides of two adjacent tubules have come together and fused. In many instances the fusion is incomplete and the limits of the individual walls may be made out. In C. mitsukurii, these conditions do not appear to be developed or at least only in a limited region about midway from infundibulum to periphery. In this species the amount of parenchyma is very much greater than in $C$. willeyi and the digestive 
canals retain their tubular character throughout. The lining cells however are not distinct in character from those of the other species, except that being more confined, they are more regular in their arrangement (cf. Fig. 14).

From the infundibulum there branch upwards two delicate tubes which open to the exterior in short papillae. As in the typical Ctenophores these arise in such a position that along the tentacular plane the lower one is to the right and the upper one to the left of that plane. These tubes appear to arise singly and a complementary blind ampulla in the alternate quadrant, such as is found in the Ctenophores, could not be demonstrated.

Finer structure of the gastric system.

The epithelium of the ventral face of Coeloplana is continued into the mouth, and lines the pharynx. In the latter regions, as noted above, the ciliated cells are large and the cilia heavier than elsewhere. The same kind of gland cells found in the body epidermis is also found in the pharynx, in all the various stages. The stomodaeal canal arising from the roof of the pharynx and leading upward into the infundibulum is lined with powerful cilia. The cells are columnar and very granular in all the preparations observed. The nucleus is often much enlarged, packed with chromatin granules and stains very densely. The cells of the infundibulum itself show the same structure as those of the canal. The cells lining the main branches of the canal system constitute a squamous epithelium. These thin walled tubes as they proceed toward the periphery and break up into finer subdivisions show marked changes in structure. The cells lining them elongate and the nucleus usually takes up a position in the basal end, - the tissue thus changing from a squamous to a stratified columnar epithelium. This gives place to a further differentiation, peripherad. The cells become greatly vacuolated, enlarge and bulge out in masses into the digestive canals. The respiratory tentacles being outgrowths of the canals themselves, are lined with the same epithelium, reduced to a thin squamous layer. In the peripheral region various metaplastic bodies become very evident: globules of fat, staining densely with osmic acid, others that take anilin acid stains and still others that stain with basic dyes. In addition all varieties of ingested food matter may be found, such as diatoms, as well as other foreign bodies, apparently half digested. These vacuolated 
cells also occur in the branches of the canal system that penetrate into the tentacle root and adjacent tissue ("tentacular canals"). There are no cilia in the canals and no evidence of a syncytium, - the cell outlines being always distinct. In certain regions these vacuolated cells proliferate in long strands or sheets, from the distal ends of which cells bud off (Fig. 32 and 39) which assume a spherical shape and float freely in the gastric canals. In C. willeyi this process is confined to the peripheral region of the body while in $C$. mitsukurii it takes place in a region approximately midway between infundibulum and periphery. In all cases these cells contain a nucleus and sometimes more than one. The cytoplasm is densely granular and seemingly not at all different in structure from that of normal epithelial cells except that there are no metaplastic granules or ingested food material. Two or three are frequently clumped together. In some instances at least there is an envelope of small cells about a large cell. It may be that these smaller enveloping cells fuse together about the nucleus of the central one, and this too may account for the presence of more than one nucleus. These cells are frequently vacuolated and the chromatin is broken up into granules. They constitute, together with a mixture of food particles, the formed elements that are to be seen circulating in the living animal and whirling about in eddies at the bases of the dorsal tentacles. In appearance they are strongly suggestive of ova. Cell division may be continued, after the cells are budded off.

The morphology of the digestive cells lining the alimentary tract in insects has been described by many observers, - notably Needham 1897, Van Gehuchten 1890, and Balbiani 1890, - and the similarity to the conditions in Coeloplana is striking. Likeweise in a hydroid, Corymorpha, МaY 1903 has described a process very similar to what takes place in Coeloplana. In the former cases the cells become "loaded" with densely staining secretion and break off or extrude portions into the digestive cavity. In Coeloplana, in contrast to the conditions in insects, the endothelial tissue is homogeneous, there is no central "nidus" and the contents of the budded off cells does not stain differently from the parent tissue. The cytoplasm never has the appearance of being sloughed off or squeezed out, such as seems to be the rule in Corymorpha and insects. The floating bodies in Coeloplana are cells arising by direct proliferation from the epithelium.

Of especial interest in the development, in Coeloplana, of typical 
"Ciliated Rosettes" as described by Chun 1880. These are identical in every way with those of pelagic Ctenophora. They lie in the walls of the gastric canals and consist of two layers of 8 cells each, surrounding a central cavity into which project strong cilia from the "rosette" cells (fig. 3 and 8 ). The beating of these cilia may cause a strong current to flow between the parenchyma and the lumen of the gastric canal.

c) Tentacles and related structures.

General description.

The sheathes of the pinnate tentacles are capacious pouches and when the tentacles are fully retracted, are swelled out into prominent bulging masses on either side of the otolith. Notwithstanding the size and capacity of these sacs, it is a constant marvel how the whole of the tentacle with its secondary branches, - often stretching down to a distance of six or eight times the diameter of the whole animal - can be accommodated within. In very transparent specimens it is seen that the pouch is not a simple sac or tube but that there are secondary diverticula leading off from the main cavity, - all crowded with writhing filaments, closely packed. In such clear specimens an appearance may be noted that is confusing and difficult to interpret without the aid of sections. The central end of the sheath appears rounded and bent back upon itself like a fishhook, the termination being directed toward the periphery. In sectioned material it may be seen that the central end of the sheath, i. e. the point nearest the otolith is expanded into a bell from the wall of which the heavy root of the tentacular muscle takes its origin in part. Lying normally below the main cavity of the sheath, but sometimes pushed to one side is what may be called the accessory sheath, a large diverticulum of the main sheath, that in surface view appears to be a continuation of the main sheath and gives the appearance of the latter being turned back, away from the center. The tentacle itself may be said to be anchored to the whole floor of this accessory sheath which spreads out into a broad flat cavity and is lined with formative tissue. The development and growth of these lining cells and of the muscle fibres connected with them is centripetal. The muscle of the tentacle, formed in this accessory branch bends sharply in the neighborhood of the otolith and enters the true sheath, forming the flaming "bell" structure alluded to. The tentacle consists of a main filament of 
muscle from which arise in one plane at regular intervals, the secondary tentacles. These are independently contractile. The ultimate branch never arises directly at the tip of the main stalk but always at one side in conformity with the arrangement of the others. The secondary tentacles are covered with typical Ctenophoral adhesive cells (lassocells, colloblasts) that sometimes, when the tentacle is fully extended, appear to be arranged in groups or batteries, especially in the region near the end of the primary tentacle. As a rule, in $C$. mitsukurii, there are no such cells on the primary tentacle itself, except near its origin. In C. willeyi, however, the primary tentacle appears to be covered uniformly with adhesive cells.

The masses of undifferentiated cells in the accessory tentacle and the muscles of the tentacle root are penetrated in all directions by the branches of the canals of the gastric system, as already described.

\section{Histological structure.}

The adhesive cells or colloblasts are of the type described and figured for typical Ctenophores (Chun, 1880; Hentwig, 1880; Schneider, 1892; Samassa, 1902; Bourne, 1900). In especially well fixed material certain details of structure may be brought out in Coeloplana which differ slightly from the appearances described by previous investigators. The fully developed cell consists of a subglobular or bellshaped cap, surmounting a rather thick spiral filament which is inserted in the outer muscle layer of the secondary tentacle. The shape of the cap seems to vary with age. In younger cells it is almost globular. Frequently in cells remote from the original formative tissue, it is elongated. Whether this is a result of growth or of differentiation persisting from the beginning could not be determined. In $C$. mitsukurii the globular form seems to be the only one. The apex of the cap is usually drawn out to a fine filament and the lower margin is likewise expanded into a delicate frill or skirt. Within the outer membrane of the cap-cell, the granular cytoplasm is arranged in a hemispherical layer of segments set like paving stones, in the center of which the nucleus lies, just above the insertion of the spiral filament. Within the spiral coil is a delicate thread running through the axis of the spiral and uniting with the latter just before its insertion in the tentacle. The spiral may be either dextral or sinistral, and the two kinds usually occur in equal proportion, side by side. Looked at from below, the cell appears as a cup into the depression of which is inserted the spiral 
filament, ending in a closed ring. Through the center of this ring the straight central filament issues (Fig. 5). Adjacent cells are covered and united by a thin membrane to which the apical filament of the cap is joined. (This membrane is found only in C. mitsukurii.)

The accessory tentacle sheath is lined with masses of cells that differentiate into the muscular tissue of the tentacle and the colloblasts surrounding the latter (Fig. 34 and 35). As the growth is continuous, all the various stages of development may be observed in different parts of the same area of tissue. The details of development are somewhat at variance with the processes described by Samassa and by Schneiner.

The undifferentiated cells are arranged in an epithelium of hexagonal cells, each of which contains a rather large and sharply staining nucleus immeshed in a reticular network. "Nucleoli" are also present, scattered about the cell. These nucleoli arrange themselves regularly about the nucleus. The nucleoli next draw near the nucleus in the center of the cell, leaving a clear open space between them and the cellwall. They do not completely surround the nucleus but cup over it in a hemisphere. The end of the cell opposite the mouth of this cup begins to elongate. At the same time the cellwall (or the cytoplasm next it) in this region begins to thicken in a spiral ridge. There is a differentiation of the cytoplasm at this stage, - that within the area surrounded by the hemisphere of nucleoli becoming denser. As the lower part of the cell elongates this differentiation is maintained and the denser part of the cytoplasm is drawn out into a cord, surrounded by the clearer cortical cytoplasm. The spiral thickening continues to increase as the cell elongates until there are a number (four or five) complete spirals formed. At about this time, the cell has an elongated pear shape, - the lower part is filled with a spiral, enclosing a dense cord of cyto lasm that is rapidly becoming filamentous, - the nucleoli surround the rather flattened nucleus in the upper end of the cell and about each nucleolus the cytoplasm begins to cleave off in segments. Later the nucleoli disappear but the segmentation persists and results in the peculiar mulberry-like appearance of the cytoplasm of the fully formed cell. After four or five of the spiral turns in the lower part of the cell have been completed, the lower margin of the cellwall breaks around, - the spiral separating from the cellwall and becoming free and the broken edge persisting as the skirt or frill. described above, about the lower margin of the cell. 
The central filamentous cord which is derived from the denser cytoplasm immediately surrounding the nucleus persists as the straight axial filament of the differentiated cell.

It will be noted that each colloblast, developed as described above is formed from a single primitive formative cell, not from two cell-elements as described by Samassa. Each one is developed independently in C. mitsukurii, while in C. willeyi they appear to arise in groups as described by Samassa for Beroe. A sheet of colloblasts in C. willeyi, developing together, is covered by a thin membrane derived from the cells themselves, each one of which is attached to it by means of its apical filament.

The muscular core. The arrangement of the muscular strands of the tentacles is quite complicated and differs considerably in the two species of Coeloplana. In C. mitsukurii there are two sets of muscles making up the core of the secondary tentacles, longitudinal and diagonal. The outermost layer is a thick sheath of longitudinal muscle fibers in which the colloblasts are rooted. The cavity surrounded by this sheath would appear as a tube, were it not for two partitions which run lengthwise of the tentacle and divide the inner cavity into three longitudinal chambers. The tissue of the outer wall and of the partitions appears to be continuous. Within the three chambers just mentioned, are located the short diagonal muscle fibers. In longitudinal section these have somewhat the feather like appearance to be seen in the body muscles of the earthworm. There is a difference however in that the short diagonal bundles in Coeloplana arising from the walls formed by the longitudinal muscle fibers focus, as it were, in a common point in the center of the cavity. The repetition of these focal points at regular intervals longitudinally of the tentacle, gives in section the appearance of apices of a series of wedges as described above. The series of diagonal muscle bundles arise however from the whole inner surface of the chambers. Filling the spaces between, there is a sort of loose connective tissue full of large irregular cells that resemble wandering giant cells.

In C. willeyi there are two sets of circular and two of longitudinal muscles. The spiral filaments of the colloblasts are inserted in an outer sheath of muscle fibers. Within this wall are five conspicuous bundles of longitudinal fibres arranged in a quincunx (in cross section). About the central cord of the five is a dense sheath of circular muscles. There are no longitudinal chambers as in the 
other species and apparently no diagonal fibers. The staining reactions are peculiar. Using Mans's Eosin-Wasserblan method followed by Orange $\mathrm{G}$, the five cords of longitudinal fibers stain intense red, - the circular sheath about the central one, blue, the outer layer, yellow. and the adhesive cells themselves purple.

The primary tentacle is made up of a thick bundle of longitudinal muscles immeshed in connective tissue and surrounding a core of the same substance, - a structure very much resembling a telegraph cable. Each muscle strand seems to be developed from a single cell by an enormous elongation of the cell body and contains many nuclei. The inner wall of the tentacular sheath is lined in part with an endothelial lining like that of the gastric canals. This is supported by a network of connective tissue and muscle cells. Elsewhere the epithelium is cubical and heavily flagellate.

A peculiar condition is observable in some preparations of C. mitsukurii. The lining cells bud off as they do in the gastric canals, and appear to take up phagocytic functions. At least in areas where a rapid proliferation is taking place the cavity of the sheath contains great numbers of similar cells that have ingested fragments of colloblasts or frequently whole cells, - spiral and all (Fig. 23). There seems to be no reason for doubting that these phagocytes arise from the inner epithelium of the sheath.

\section{d) The otolith.}

The otolith with its accessory structures does not appear to differ from the general Ctenophore type. The otolith itself consists of a number of calcareous granules held in an organic matrix and swung in a cup by means of cilia. The whole apparatus is usually sunk some distance below the surface when Coeloplana is contracted and the overlapping edges of the epithelium appear like fleshy lips. The cup is subglobular in shape and closed over above by a membrane formed by the fusion of cilia springing from cells in the cupwall. The cells whose cilia support the otolith lie in a zone about the lower half of the cup. The cilia are long and arise from the columnar cells of the ciliated zone in densely staining knots of protoplasm as previously described for the cilia in other parts of the body. The cilia form a complete circle about the otolith without appearing to fuse with each other. However, instead of being attached to the otolith evenly on all sides they are gathered together 


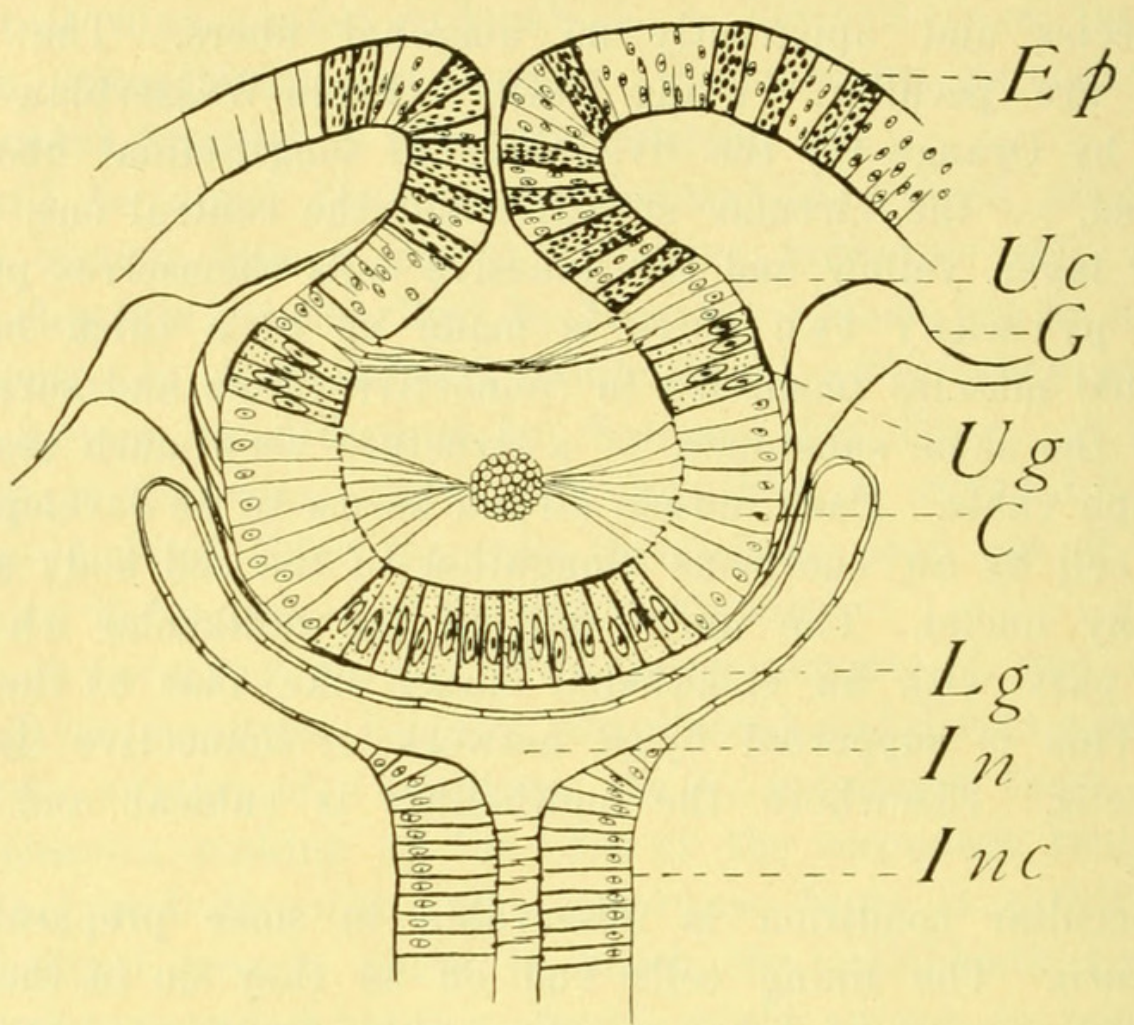

Fig. A. Vertical section through otolith cup and adjacent structures (semidiagrammatic). Plane of section bisects the angle formed by the tentacular and sagittal planes of body.

Ep Epithelium of dorsal surface composed of gland cells and supporting syncytium. Uc Upper zone of ciliated cells whose cilia fuse to form a covering membrane. $G$ Nerveganglion. $\quad U g$ Upper layer of a gland cells. $L g$ Lower layer of same. $C$ Zone of ciliated cells supporting otolith. In Infundibulum. Inc Flagellate epithelium lining infundibular canal.

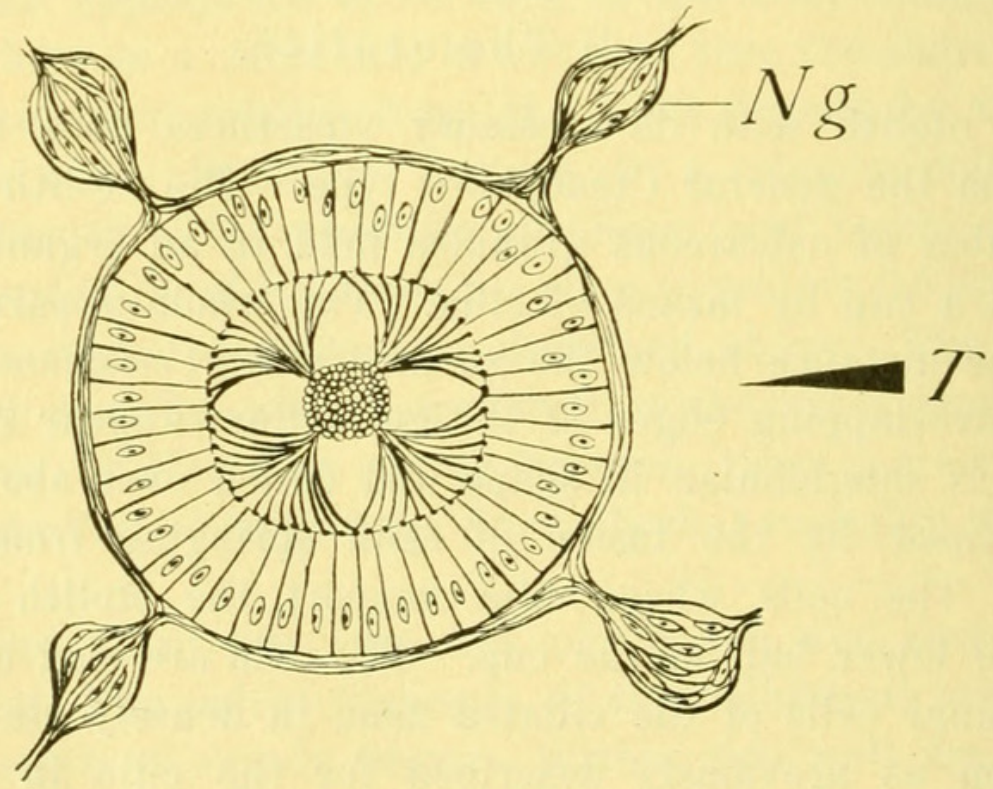

Fig. B. Horizontal section (semidiagrammatic) through otolith and capsule showing the otolith sustained by the brushes of cilia arising from the ciliated zone (see text).

$\mathrm{Ng}$ Nerve ganglion. $T$ Tentacular plane. 
in a sort of spreading brush or fan, the apex directed against the otolith at four equidistant points, an arrangement that recalls the four $\mathrm{S}$ shaped supports in the Cydippida. In the center of the ciliated zone (i. e. directly below the otolith) and also in a second zone above it the cells forming the wall of the cup are not ciliated but glandular. The nuclei are very large and deeply staining and the cells are usually crowded with small granules.

Just outside the otolith capsule in the angles formed by the intersecting tentacular and sagittal planes are four large nerve ganglia (cf. KовотNeFF) that send off fibers to form a sort of diffuse peripheral system, and on the other hand supply fibers that surround the lower part of the capsule as an enveloping sheath. Each ganglion is directly opposite the point of insertion of the supporting cilia on the otolith. The cells of the nerve tracts and ganglia are large, with large nuclei, and stain intensely in methyl blue.

In addition to the central sense organ the yellow pigment spots on the periphery probably have a sensory function tho I have been unable to work out any details regarding them.

e) Parenchyma and musculature.

In conformity with its life habits Coeloplana has a much firmer body consistency than purely pelagic forms. The spaces between the gastric canals the tentacle sheaths and the epidermis are small and filled with a parenchymatous tissue well calculated to withstand the various strains to which the body is subjected. From the basement membrane of the epidermis fine branching muscle processes enter the parenchyma and ramify throughout its extent. The cell elements are of various sorts, -1 ) delicate much branched cells with dendritic processes; 2) long usually wavy and thickened muscle cells with terminal branches only, which stain intensely with methyl blue; 3) oval or irregular cells with large nucleus, which may be early stages in development of the elongate muscle cells.

There is another variety of cell of doubtful nature to be found scattered through the parenchyma. These are very long and thick, irregular in shape and resemble a crumpled up sausage. The cytoplasm is granular in some, alveolar in others. No nucleus was. demonstrable. They may possibly be parasitic in nature. 


\section{General considerations.}

Struck by the similarity in habits and form between Coeloplana and the Polyclads, Lang, 1884, attempted to utilize Kowalevskr's discovery as the basis of a possible origin of the latter from the Ctenophores through Coeloplana. While it is not probable that any morphologist accepts LaNG's hypothesis nowadays it may be noted that in addition to the erroneous homologizing of the axes of the body in the Ctenophora, discussed by WiLLex, LANG was no doubt led astray by the reviewer in the Zoologischer Anzeiger (vide ante) so that he homologized the excretory tubes leading upward from the infundibulum (a structure characteristic of Ctenophores) with the anterior branch of the gastric system of the Polyclads.

Willex, 1896, with the more exact knowledge obtained from his own and KonotnefF's studies on Ctenoplana avoided this mistake but contended that Ctenoplana is a primitive form, rather warmly denying any imputation of its being degenerate, as a "groundless assumption". He places his Ctenoplana in an order, the Archiplanoidea, from which he derives the Ctenophora on the one hand and the Platyhelminthes on the other. It will be seen that the value of this arrangement depends wholly upon whether Ctenoplana is to be considered a primitive form or not and the arguments WiLLEY advances in support of his assertion are not wholly conclusive. It must be conceded that Ctenoplana stands midway between Coeloplana and the Cydippid Ctenophores, in regard to either its primitiveness or its "degeneracy". Coeloplana is wholly without costae; Ctenoplana is scantily provided with costae. Coeloplana has practically given up, or, from Willex's point of view, never acquired the pelagic habit while Ctenoplana both swims and crawls.

If Ctenoplana is primitive, then Coeloplana is certainly so to a greater degree, and if we find in Coeloplana structures that can only be explained as the result of the reduction, through disuse, of structures characteristic of pelagic Ctenophores and associated with their pelagic habit, then the presumption is clear that it cannot be a primitive form in WILLEY's sense and that the Ctenophora cannot be derived from it. In fact the weight of the morphological evidence bears out the conclusion that Coeloplana is a very highly specialized Ctenophore derived from the Cydippida.

Among the structures found in Coeloplana which are characteristic of the pelagic Ctenophores may be mentioned 1) the median funnel 
and the excretory pores, 2) the adhesive cells or colloblasts of the pinnate tentacles which are the unique character of the Ctenophora. 3) the otolith and 4) the ciliated rosettes, which are identical with those found in the Ctenophora, even to the number of cells composing them. The last two characters, especially the last, must be considered as vestigial structures reminiscent of a previous pelagic habit. The otolith, the essential organ for orientation in a free swimming Ctenophore, we would hardly expect to find developing in a sluggish littoral form like Coeloplana but its presence is explicable on the supposition that Coeloplana is descended from a pelagic form. The ciliated rosettes in the pelagic Ctenophores function without doubt as means for hastening the absorption of digested food substances into the mesogloea lying between the relatively widely separated gastric canals. In Coeloplana with its great reduction in amount of parenchyma due to the flattening out of the body, and the ramifications of the canal system, such organs must be almost functionless.

While the characters just mentioned have evidently been preserved unchanged in the adoption of a littoral habit, other structures have been modified in accommodation to that habit. The costae have disappeared. In Coeloplana the flattening of the body has also brought about attendant changes such as the vertical compression of the flaring proximal portion of the tentacle sheath to produce the "accessory sheath", the much greater development of the muscular system, the extensive anastomosing of the gastric canals and the conversion of the stomodaeum into a capacious pharynx.

A careful examination will also show how the arrangement of the gastric canals in Coeloplana may be merely a modification of the system in the Cydippida. It will be recalled that in a typical Cydippid the mouth opens into a long stomodaeum leading into an infundibulum from which branch out certain definite canals. Two of these, the perradial canals, lying in the tentacular plane, send off an interradial canal on either side and another one directed downwards, the stomodaeal canal, and are continued distally into the muscle of the tentacle as the tentacular canals. Each perradial canal divides in turn into two adradial canals that terminate in vertical expansions underlying the rows of costae. Complementary to the stomodaeum the infundibular canal leads upwards from the infundibulum to the base of the otolith, communicating with the exterior by the two excretory pores.

In Coeloplana, on account of the great flattening out of the body, 


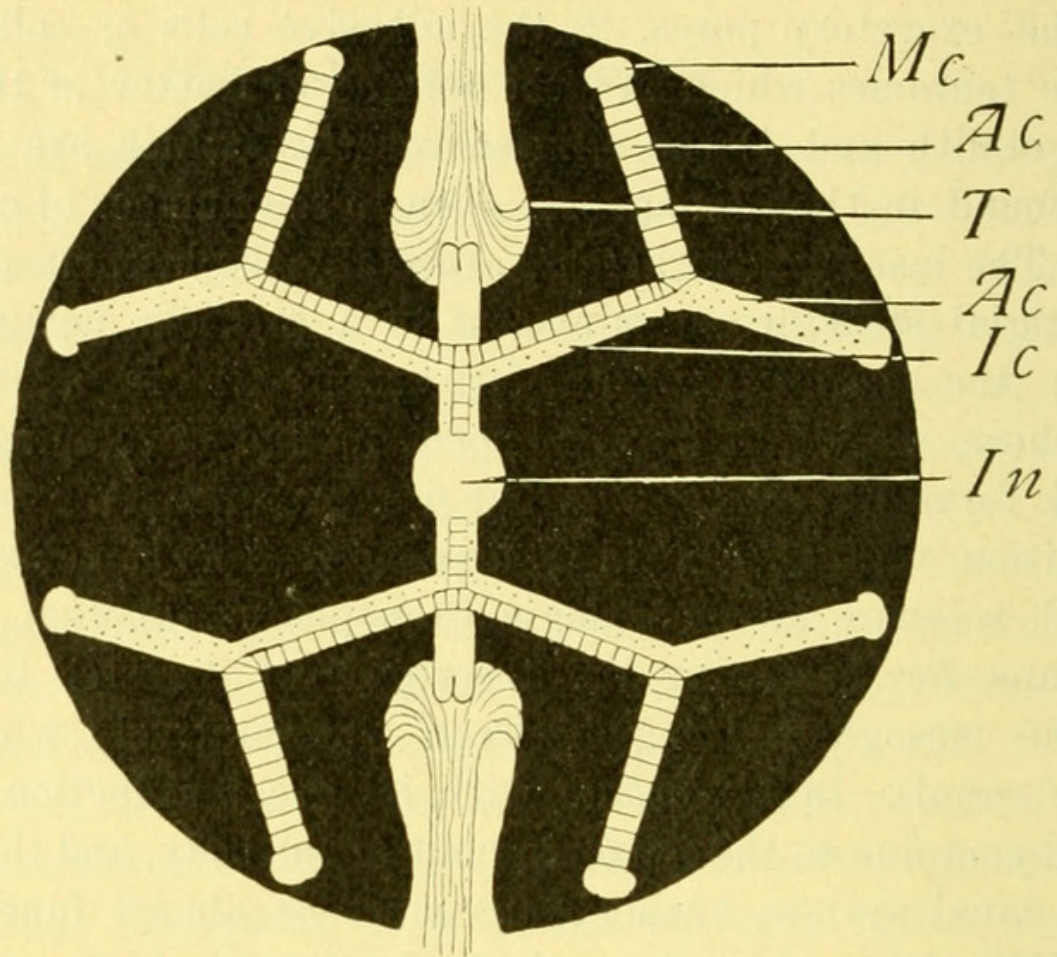

Fig. C. Diagram of canal system of Cydippid Ctenophor (after Parker \& Haswelu). $M c$ Meridional canal. $A c$ Adradial canal. $T$ Tentacle in sheath. Ic Interradial canal. In Infundibulum.

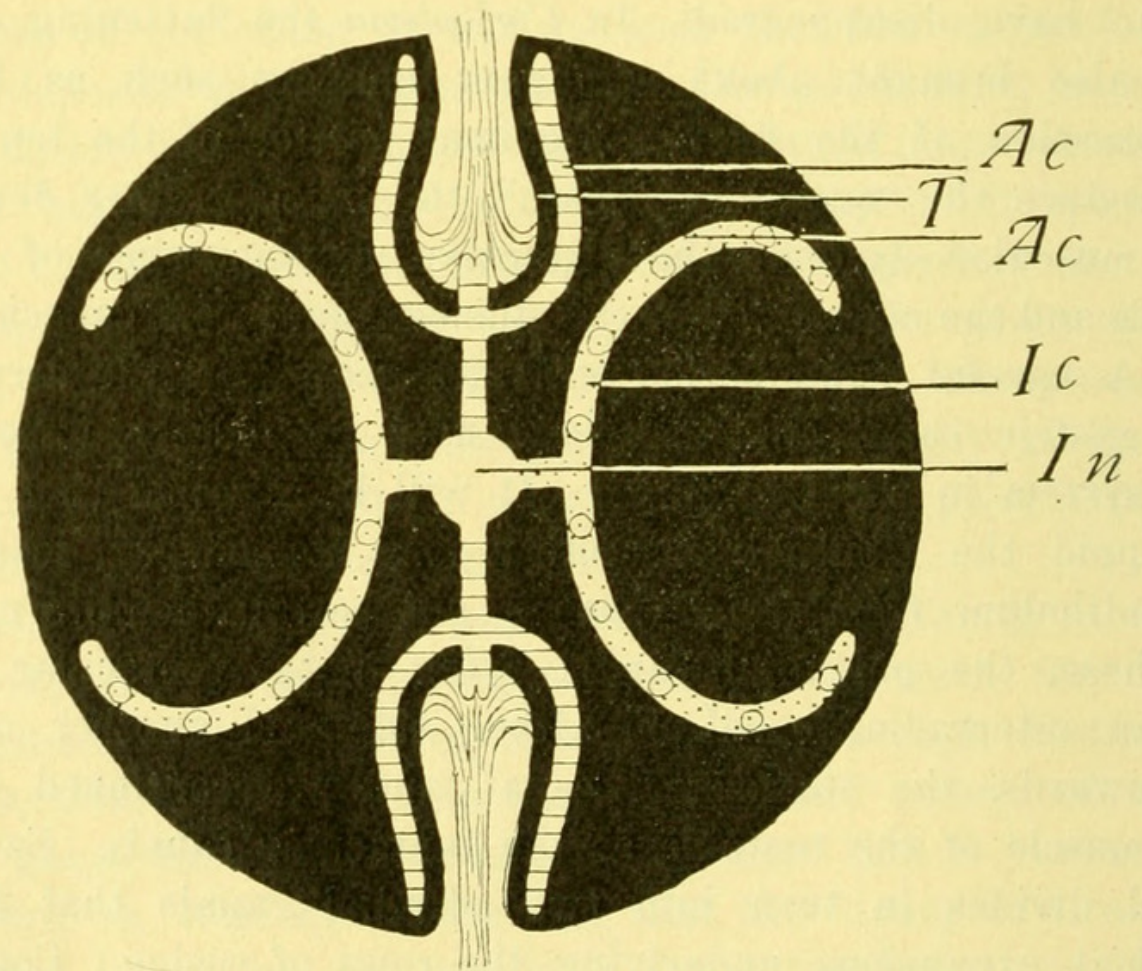

Fig. D. Diagram of canal system of Coeloplana showing the probable derlvation from the Cydippid tyle.

$A c$ Adradial canal. Ic Interradial canal.

The dotted and striped regions represent similar portions of the canals in both figures. The interradial canals of Fig. C are supposed to be split to the infundibulum and united in the sagittal plane, the identity of the interradial canal being thus lost. 
this infundibular canal has disappeared and the lower part of the stomodaeum has become modified as the pharynx. From the infundibulum the two perradial canals, as in the Cydippida, lead directly into the roots of the tentacles, but before entering the tentacle base they spread out in an enclosing network or system of sinuses surrounding the sheath, as described before. A glance at the text figures (C and $\mathrm{D}$ ) will show the probable origin of all these "sinuses". We have only to imagine the stomodaeal canal bent upward and under the sheath (a natural result of the flattening of the body) and the splitting off of the adradial canals from the interradial canals to be continued down to the perradial canal and we would have the tentacle sheath enclosed on three sides by canals, the confluence of branches of which would give the enclosing network mentioned. The other two adradial canals would be left free and would run from the perradial canal to the periphery (Fig. D). In Coeloplana the proximal portions of these canals seem to have joined in the sagittal plane to form one one stem canal, which is, however, frequently cleft to the infundibulum (vide ante page 52). From these main trunks arise the anastomosing branches of the gastrovascular system as previously described. The Cydippid meridional canals have disappeared in Coeloplana.

\section{Summary.}

We may summarize the morphological facts described in the foregoing pages as follows:

1. The epithelium is similar to that in pelagic Ctenophores with the exception of the cilia on the ventral surface.

2. The epithelial gland cells apparently pass through the same cycle of changes as described by Samassa for the Ctenophores.

3. The coloration is due to iridocyte-like pigment cells in the subepithelial structures.

4. The gastrovascular system consists of a capacious thickwalled pharynx leading upwards into an infundibulum underlying the sense organ. From this two canals arise, in the tentacular plane, enclosing the tentacle sheathes in an anastomosing network. Two others in in the sagittal plane arise in the same way but soon divide so as to form four canals converging towards the tentacles, roughly in the form of a figure " 8 ".

5. The arrangement of these canals has apparently been derived Zool. Jahrb. XXIV. Abt. f. Anat. 
from the Cydippid Ctenophore type by such an alteration of the Cydippid canal system as would naturally come about in the adoption of littoral habits by a pelagic form.

6. There is no circumperipheral canal and the multitude of small canals throughout the body are to be considered merely as arborizations of the main canals mentioned above.

7. The canals are lined with loose vacuolated endothelial cells that bud off into the lumen of the canals.

8. The pinnate tentacles with their "adhesive cells" (colloblasts) are practically identical with those of typical Ctenophores.

9. The method of formation of the colloblasts is as follows. The chromatin substance in the original mother cell arranges itself in a central mass, which we may call the nucleus and a number of smaller masses ("nucleoli") which arrange themselves in a hemisphere about the former. Each nucleolus cleaves off the adjacent cytoplasm into blockss (but without the formation of cell walls) so that the original cell has a mulberrylike appearance. This forms the cap of the cell. The cytoplasm differentiates into the spiral cord and the central filament of the developed cell and by its elongation the cell attains the shape and size typical of its kind. The "nucleoli" disintegrate leaving only the central nucleus at the base of the cup. The developed colloblast arises then from one undifferentiated cell and not from the union of two.

10. Phagocytes are to be found in the tentacle sheath, filled with the ingested fragments of colloblasts.

11. The otolith is typical of the Ctenophora and is supported by brushes of cilia arising from the wall of the cup.

12. There is a rudimentary nervous system with four ganglia symmetrically disposed about the otolith capsule.

13. The weight of the morphological evidence supports the assumption that Coeloplana is a very highly specialized Ctenophore related to, or derived from the Cydippida. ${ }^{1}$ )

1) The true position of Coeloplana and its relationship with other groups cannot be certainly decided until its development has been worked out. Unfortunately the writer has been unable to shed any light upon this matter. The only times when it was possible for him to collect were spring and late summer and it is possible that the animals attain sexual maturity at a different season or that they may reproduce at greater depths or in a different environment from that in which they were found. 


\section{Literature.}

1902. Аввотт, J. F., Preliminary Notes on Coeloplana, in: Annotat. zool. Japon., Vol. 4, p. 103.

1890. Balbiani, Etudes anatomiques et histologiques sur le tube digestiv des Crytops, in: Arch. Zool. expér., Vol. 11.

1900. Bourne, G. C., The Ctenophora, in: Lankester's Treatise on Zoology, Part 2, Chap. 7 (Reproduction of KowaLevsky's original figure of Coeloplana).

1880. Chun, C., Die Ctenophoren des Golfes von Neapel, in: Fauna Flora Golf Neapel, Monogr. 1.

1880. Hertwig, R., Ueber Bau der Ctenophoren, in: Jena. Z. Naturw., Vol. 14.

1892. Samassa, PaUl, Zur Histologie der Ctenophoren, in: Arch. mikrosk. Anat., Vol. 40, p. 157.

1902. Schneider, K. C., Lehrbuch der vergleichenden Histologie, p. 280.

1886. Korotneff, Alex., Ueber Ctenoplana Kowalevski, in: Z. wiss. Zool., Vol. 43, p. 242.

1880. Kowalevsky, A., Coeloplana Metschnikowii, in: Извъ̌ст. общ. льб. есгествоз. Труды зоол. отдъла, Vol. 1.

1880. - Abstract of above, in: Zool. Anz., p. 140.

1884. Lang, Arnold, Die Polycladen des Golfes von Neapel, in: Fauna Flora Golf Neapel, Monogr. 11.

1903. MaY, Morphology and development of Corymorpha, in: Amer. Naturalist, Vol. 37, p. 579.

1897. Needhan, The digestive epithelium of Dragonfly nymphs, in: Zool. Bull., Vol. 1, p. 103.

1890. VAN GeHUChten, Recherches histologiques sur l'appareil digestiv de la larve de la Ptychoptera contammata, in: La Cellule, Vol. 6.

1896. Willey, Arthur, On Ctenoplana, in: Quart. J. microsc. Sc. (N. S.), Vol. 39, p. 323. 


\title{
Explanation of plates.
}

\author{
Plate 8 .
}

Fig. 1. Sketch from life of Coeloplana willeyi, on an Ulva frond. $10: 1$. The cylindrical dorsal respiratory tentacles are protruded; the armed tentacles retracted within their sheathes.

Fig. 2. Sketch from life of Coeloplana mitsuliurii floating on the surface of the water. $2: 1$.

Fig. 3. A ciliated rosette viewed from the inner (parenchyma) side. $900: 1$. m. $c$ muscle cell, $c . r$ ciliated rosette, $c . t$ "connective tissue cells".

Fig. 4. A colloblast or adhesive cell of the tentacles (C. willeyi). $1350: 1$. $n$ nucleus of cap cell, $c$ mulberrylike arrangement of cytoplasm of cap cell, sk skirt of cap cell, $s p$ spiral filament, $f$ central filament, $o . m$ outer longitudinal muscle layer of secondary tentacle, $g . c$ giant cell floating in interstices between muscle filaments of secondary tentacle, $\mathrm{m}$ brushes or converging wedges of transverse muscle fibers, $i . m$ inner layer of longitudinal muscles, $c$. o central core of the inner longitudinal muscles.

Fig. 5. Diagram to show insertion and relation of central and spiral filament to cap cell.

Fig. 6. Sketch from life of otolith region. ca. 20:1. Surrounding the otolith is a ring composed of cells that support the otolith. The outer yellowish ring is made up of the belt of gland cells of the cup. On account of their equatorial position they appear in surface view to be external to the band of supporting cells. Surrounding the lips of the depression are the branched pigment cells.

\section{Plate 9.}

Fig. 7. Section through epithelium, parenchyma and tentacle sheath of C. mitsukurii. $300: 1$. ep epithelium, composed of a syncytium of epithelial cells interspersed with gland cells, the latter in this preparation are in the beginning of "Stage C", $s . c$ flagellate cells lining the tentacle sheath, pig. $c$ pigment cell of the parenchyma, $m . b$ group of muscle cells in cross section, $x$ group of bodies of uncertain nature, possibly parasitic in nature. Interspersed in the parenchyma between the outer epithelium and that of the lining of the sheath are numerous isolated muscle cells and connective tissue cells. The former form a rather dense layer just under the epithelium.

Fig. 8. Ciliated rosette viewed from the side of the gastric canal, out of which it opens. $900: 1$. ep squamous epithelium lining the canal, c. $r$ ciliated rosette. 
Fig. 9-13. Cellular elements floating in the circulating fluid of the canal system. 900:1. Fig. 9, 11 and 13 show the typical forms resulting from coalescence of several cells. Compare with figure 39, plate 5 .

Fig. 14. Cross section through skirt of $C$. mitsukurii near periphery. $300: 1$. g. can cross section of a gastric canal. Note the contrast between the secreting and non-secreting portions of the endothelial lining. Between the epithelium and the canals is a loose parenchyma made up almost wholly of branched connective tissue cells.

Fig. 15. Horizontal section (slightly tangential) through otolith capsule. C. willeyi. $160: 1$. cav cavity of the capsule, gl a few gland cells of the glandular zone, $n v$ ganglia and nervous investment of the surface of the capsule, in cavity of the infundibulum which underlies the capsule and comes up about its sides. It is included in this section owing to the fact that the section is not cut quite horizontally.

Fig. 16. C. mitsuliurii. Vertical section through a dorsal respiratory tentacle (quite strongly contracted). 365:1. ep dorsal epithelium, p. $c$ pigment cells of parenchyma, en endothelial lining of gastric canals, $g$. can diverticulum of gastric canal entering the tentacle and branching with it. Numerous cross sections of muscle bundles are to be seen in the parenchyma as well as numerous long independent muscle cells.

Fig. 17-21. Cell elements of the parenchyma. 900:1. Fig. 17 and 21 ; typical connective tissue cells with forked processes found where the parenchyma is loose and spongy (cf. Fig. 24). Figs. 18 and 20, connective tissue cells found in denser parenchyma; Fig. 20 is possibly a type of an early stage of development. Fig. 19 is a solitary muscle cell such as is found throughout the parenchyma.

Fig. 22. Cell elements of the circulating fluid of the gastric canal system. $900: 1$. Division goes on after separation from the parent endothelium.

Fig. 23. Phagocyte from tentacular sheath that has ingested portions of colloblasts. $n$ nucleus. $900: 1$.

Fig. 24. Ciliated epithelium of ventral surface of body. 300:1 (cf. Fig. 7). The gland cells $(g l . c)$ are in Stage B of the cycle, $m b$ muscle bundle cut transversely, $m . l$ layer of muscle cells immediately underlying the epithelium, ep and separating it from the loose parenchyma.

\section{Plate 10.}

Fig. 25-31. Stages in the development of a colloblast (C. willeyi). $900: 1$. Fig. 25, 26, 27 are looked at from above, the rest from the side. Fig. 25, the undifferentiated cell. Fig. 26, the chromatin begins to aggregate into "nucleoli". Fig. 26. These concentrate about the nucleus proper. Fig. 27. The cytoplasm begins to differentiate into a denser inner column and a spiral outer thickening. Fig. 28-29. The nucleoli have blocked off the cytoplasm about the nucleus into the typical mulberry shape, the central column has thinned and the spiral filament has become much more definite. Fig. 30, the typical spiral filament 
established by the breaking away of the margin of the cell to form the cup. The nucleoli are disappearing.

Fig. 32. A strand of endothelium of a gastric canal of $C$. willeyj ; budding off cells into the circulating stream. 900:1. a) cells just divided, b) one just separating from the strand.

Fig. 33. Flagellate epithelium of the floor of the pharynx. 800:1. gl. $c$ a gland cell in Stage C, - the greater part of the granules have apparently been thrown out - the nucleus is visible and apparently Stage A is beginning in the lower part of the cell. $l$ lacunae between cells due to shrinkage in fixation.

Fig. 34. Horizontal section through root of tentacle muscle and accessory sheathes at sides, $C$. willeyi. $80: 1$. g. can lumen of branches of gastric canal system (tentacular canal) running into the root of the tentacle from the infundibulum, en endothelial lining of canal system, $m . l$ formative layer of undifferentiated cells from which both muscle and colloblasts arise (in this region largely muscle cells), $m . c$ packing of muscle cells about the sheath, ten muscle of the tentacle proper.

Fig. 35. A portion of Fig. 34 (X) more highly magnified. $900: 1$. en endothelial lining of canal system, $m$. $c$ muscle cells converging to form a fiber $(m f)$ of the tentacle.

Fig. 36. Epithelial cells of the dorsal surface. 360:1. a gland of doubtful nature possibly similar to the "albumin cell" described by others. The other two are typical gland cells in Stage C. $b$ one discharging its contents, g granules passing to the exterior.

Fig. 37. Transsection of secondary tentacle of C. willeyi. 95:1. Most of the colloblasts are torn off. $i . m$ inner layer of longitudinal muscles of tentacle (cf. Fig. 4).

Fig. 38. Transsection (thick) of secondary tentacle of C. mitsukurii. $300: 1$. col colloblasts, o. c. $m$ outer layer of circular muscle in which the filaments of the colloblasts are inserted, i. c. $m$ inner circular layer, $o . m$ outer longitudinal muscle strands, $i . m$ inner longitudinal muscle strand.

Fig. 39. Strands of endothelium budding off cells into the canal system. $900: 1$. $s$ septum between two adjacent canals, a typical cell with central large nucleus surrounded by clear space, $b$ suggests the origin of such a cell in the fusion of several smaller ones.

Fig. 40. Flagellate epithelium of stomodaeal canal. C. willeyi. $800: 1$. 


\section{$2 \mathrm{BHL}$ Biodiversity Heritage Library}

Abbott, James Francis. 1907. "The morphology of Coeloplana." Zoologische Jahrbücher. Abteilung für Anatomie und Ontogenie der Tiere 24, 41-70. https://doi.org/10.5962/bhl.part.10037.

View This Item Online: https://www.biodiversitylibrary.org/item/43589

DOI: https://doi.org/10.5962/bhl.part.10037

Permalink: https://www.biodiversitylibrary.org/partpdf/10037

\section{Holding Institution}

MBLWHOI Library

\section{Sponsored by}

MBLWHOI Library

\section{Copyright \& Reuse}

Copyright Status: NOT_IN_COPYRIGHT

This document was created from content at the Biodiversity Heritage Library, the world's largest open access digital library for biodiversity literature and archives. Visit BHL at https://www.biodiversitylibrary.org. 